\title{
Options for Operation and Maintenance Partnerships - A Case Study of Rupike Irrigation Scheme, Zimbabwe
}

\author{
Emmanuel Mwendera ${ }^{1}$, Pius Chilonda ${ }^{1} \&$ Patrick Chigura ${ }^{2}$ \\ ${ }^{1}$ International Water Management Institute, Southern Africa (IWMI-SA), Silverton, Pretoria, South Africa \\ ${ }^{2}$ International Water Management Institute, Southern Africa (IWMI-SA), Masvingo Project Office, Masvingo, \\ Zimbabwe \\ Correspondence: Emmanuel Mwendera, International Water Management Institute, Southern Africa (IWMI-SA), \\ Private Bag X813, Silverton, Pretoria 0127, South Africa. Tel: 27-76-079-9232. E-mail: yoyoejm@yahoo.com
}

Received: December 21, 2012 Accepted: April 25, 2013 Online Published: July 8, 2013

doi:10.5539/sar.v2n3p136 URL: http://dx.doi.org/10.5539/sar.v2n3p136

\begin{abstract}
Adequate operation and maintenance (O\&M) of irrigation infrastructure sustains irrigation scheme facilities, reduces repair costs, helps the system last longer, and keeps irrigation efficiency at design levels. In cases where farmers do not have sufficient capacity to operate and maintain the irrigation infrastructure sustainably, it is necessary for the farmers to enter into partnerships with external entities. The paper presents assessment of partnerships required for small-scale farmers at Rupike Irrigation scheme, in Masvingo, Zimbabwe, to operate and maintain their irrigation infrastructure sustainably. The O\&M domain in the irrigation scheme consisted of five components of water acquisition (WA), water transmission (WT), water pumping (WP), water distribution (WD) and field water application (WAP). Group discussions of the farmers were held to obtain farmers' input in the identification of components and activities for which partnerships were required. It was proposed that the scheme requires public-community partnership $\left(\mathrm{P}_{\mathrm{U}} \mathrm{CP}\right)$ to operate and maintain the dam, public-private-community partnership $\left(\mathrm{P}_{\mathrm{U}} \mathrm{P}_{\mathrm{VT}} \mathrm{CP}\right)$ to operate and maintain the pump house, private-community partnership $\left(\mathrm{P}_{\mathrm{VT}} \mathrm{CP}\right)$ to operate and maintain the transmission and mainline and field distribution pipelines, and public-community partnership $\left(\mathrm{P}_{\mathrm{U}} \mathrm{CP}\right)$ to operate and maintain field application and crop production systems. It was also proposed that each partnership be formalised through contractual arrangements. It was recommended that the farmers improve funding for O\&M through increased contributions as well as through partnerships with the private sector. It was also recommended that, for effective partnerships in irrigation schemes, it is important to analyse the scheme components and identify where and how such partnerships are needed for sustainable O\&M of scheme infrastructure.
\end{abstract}

Keywords: partnerships, operation and maintenance, small-scale irrigation schemes, sustainability

\section{Introduction}

Maintenance of irrigation systems is crucial to guarantee the sustainability of irrigated agriculture (Jurriens \& Jain, 1993). Effective and timely maintenance of irrigation schemes can improve the efficiency of water distribution and help to manage demand (FAO, 1999). While accurate assessment of resources and good engineering are basic to the success of small-scale irrigation schemes, an effective operation and maintenance (O\&M) system is one of the factors that determine long-term performance and sustainability of a small-scale irrigation scheme (Small \& Svendsen, 1990; Chancellor \& Hide, 1997; Bos et al., 2005; Gorantiwar \& Smout 2005; World Bank, 2007; Hedayat, 2011). Proper operation, maintenance and sustainability of an irrigation system depend on effective functioning of irrigation scheme institutions such the water user association or irrigation management committee (Bembridge, 2000; Mishra et al., 2011). Effective scheme operation and maintenance are adversely affected by weak management and inadequate maintenance and operating budgets (Chibisa et al., 2008). The quality of irrigation system O\&M is affected not only by the amount of resources made available to operate and maintain systems, but also by the institutional arrangements under which they are provided (Small et al., 1989; World Bank, 2006).

Adequate O\&M is a necessary condition to sustain irrigation benefits and ensure that the scheme facilities remain functional. Regular maintenance of irrigation equipment reduces repair costs, helps the system last longer, and keeps irrigation efficiency at design levels (Hill et al., 2008). Studies have shown that poor maintenance of 
infrastructure and equipment coupled with high maintenance costs are some of the main factors that contribute to poor performance of irrigation systems (Degǐrmencǐ et al., 2003; Kuscu et al., 2009; Mnkeni et al., 2010; Hedayat, 2011; Fanadzo, 2012). Indeed, one of the O\&M related problems in small-scale irrigation systems is that there is often a vicious circle in which insufficient maintenance of irrigation infrastructure leads to downgrading infrastructure which in turn leads to poor performance and low cost recovery (Prèfol et al., 2006). In cases of revitalised irrigation systems, effective operation and maintenance of the irrigation system is generally considered to be one of the important determinants of the degree of utilisation of the potential of a revitalized irrigation scheme (Mitra, 1997).

\subsection{Operation of an Irrigation system}

Systems operation is the process that ultimately determines whether irrigation achieves, or fails to achieve, the objectives of providing water service to users and controlling the impacts of irrigation on the water basin. The operations of an irrigation system require the mobilization of a range of resources-human, transportation, and hardware and software-to manipulate the system (Renault \& Godaliyadda, 1999). These resources must be allocated and used in the most efficient way for implementing scheduled changes to the system status and to respond to unscheduled perturbations. For the farmers to realize the full benefit of an irrigation system, they must operate the system according to design. It is important to match proper design of a sprinkler system with proper operation to ensure success of the system. For example, under a properly operated system, a combination of the nozzle size, appropriate available pressure and set duration produce an application rate that matches the intake rate of the soil and evenly distributes the amount of water needed to refill the depleted soil water in the crop root zone (Hill et al., 2008).

\subsection{Maintenance of an Irrigation System}

Irrigation scheme maintenance activities are designed to ensure the capabilities of physical infrastructure to deliver the intended amount of water over the life time of the infrastructure. It is more economical to maintain an irrigation system at a satisfactory level than allowing the system to deteriorate under poor maintenance and then trying to rehabilitate it. According to World Bank (2007), the maintenance function of an irrigation system comprises three activities: predefined programs (preventive maintenance); breakdown services (curative maintenance); and daily upkeep. Generally, maintenance activities consist of routine maintenance; emergency works; and scheme improvement. Routine maintenance activities have to be repeated throughout the lifetime of an irrigation scheme to keep it functioning such as greasing of gates, removing vegetation from embankments, canals and drains, removing silt from canals, drains and structures, repairs to gates and measuring structures, repainting of steel structures, installation of water level gauges, and maintenance and small repairs of pumps and engines. Much of the routine maintenance of irrigation schemes consists of very simple operations that can be done by the farmers. Some of the routine maintenance activities require skilled artisans, such as a mechanic, a mason, a carpenter and a painter. Larger routine maintenance jobs such as major repair or replacement of gates, pumps, and engines, large-scale silt clearance from canals and drains, and large-scale maintenance of roads and embankments are usually done between irrigation seasons.

Ideally, emergency works require immediate and joint action by the scheme farmers and government agencies, such as Department of Irrigation Development, to prevent or reduce the effects of unexpected events such as: critical failure of pumps or head-works, causing interruption of irrigation water supply. The routine maintenance and emergency repairs are aimed at keeping or restoring the technical infrastructure in the condition it was in when it was newly built (Snelle, 1996). For the farmers to be able to deal with emergency works, they must be trained so that they know what to do as soon as they arrive on the scene, such as cutting off the power to an overheated pump.

In some cases, works are required to make some alterations to make the system fully operational. In such cases, improvements in the infrastructure are necessary to ensure that the scheme continues to deliver services that correspond with farmers' needs in a changing environment. In cases where conditions change, both inside and outside the scheme, improvements are necessary to ensure that the scheme continues to deliver services that correspond with farmers' needs (Snelle, 1996).

\subsection{Financing of Operation and Maintenance Activities}

Financing O\&M is related to the nature of partnership for operating and maintaining the irrigation system. The collection of irrigation service fees is good practice to finance and sustain O\&M activities (Morales \& Mongcopa, 2008). Morales and Mongcopa (2008) reported that the factors that lead to inadequate O\&M in irrigation schemes include lack of funds for O\&M and poor revenue collection from scheme beneficiaries. In many developing countries, governments and/or irrigation scheme management institutions fail to set up 
irrigation charges that cover actual O\&M costs (Shah et al., 2002). In cases where irrigation charges are set up, there is often the problem of failureofcollecting these charges. According to Biswas (1984), O\&M is one of the most underestimated aspects of irrigation systems in developing countries (Biswas, 1984). In most cases, funds available for O\&M are most inadequate, and often maintenance efforts continue to be postponed, until a major crisis appears at which time it can no longer be postponed. Postponing maintenance leads to reduced efficiency of the irrigation system, and during a crisis situation, generally the problem faced is more complex to resolve technically and more funds have to be spent than had the maintenance works been carried out on a regular basis (Biswas, 1984). Financing O\&M is linked to sustainability in that, the ability of the scheme to generate sufficient income to satisfy the household income expectations of the irrigators, and cover basic operational and maintenance costs of the irrigation infrastructure determines the viability of an irrigation scheme (Kamara et al., 2001). Abernethy (2002) and Oriola (2012) argued that funding of recurrent costs of operation, maintenance and management for existing users of irrigation schemes through O\&M partnerships is one of the ways private investment can be directed in agricultural water.

\subsection{Partnerships in Irrigation Systems}

One of the problems the irrigation sector faces is lack of asset maintenance. Recent decades have shown some concern and effort to improve the performance of the sector, with the focus switching from on-farm improvement, to farmer involvement through participatory irrigation management and irrigation management transfer, and to quality service-oriented organizations. The proposed options for partnership should really be viewed as a logical sequence to these successive efforts, with a differentiated treatment of the various functions in the different irrigation domains. Numerous attempts have been made to try to find a way out of this problem, and the idea of trying to involve the private sector through public-private partnership $\left(\mathrm{P}_{\mathrm{U}} \mathrm{P}_{\mathrm{VT}} \mathrm{P}\right)$ has been growing (Prèfol et al., 2006; World Bank, 2006). There are several management typologies of partnership in irrigation system management such as Non-Government Organization (NGO), private sector or public-private sector entity. The NGO type of partnership is unusually mediated through the association of Irrigation Water Users Association (IWUA). Public-private partnership $\left(\mathrm{P}_{\mathrm{U}} \mathrm{P}_{\mathrm{VT}} \mathrm{P}\right)$ is considered one of the ways of bringing in efficient management skills and fresh funds and of relieving government of the fiscal and administrative burdens in the management of irrigation schemes (World Bank, 2006).

The traditional approach of defining partnerships for an irrigation scheme has been largely in reference to overall scheme governance and management - and not specifically to the different partnerships required in the different domains- such as the O\&M domains. These partnerships have been based on the assumption that an irrigation scheme is a homogeneous system, and that the entire system can be operated and maintained simply by one type of partnership-be it public-private partnership $\left(\mathrm{P}_{\mathrm{U}} \mathrm{P}_{\mathrm{VT}} \mathrm{P}\right)$, public-community partnership $\left(\mathrm{P}_{\mathrm{U}} \mathrm{CP}\right)$ or private-community partnership $\left(\mathrm{P}_{\mathrm{VT}} \mathrm{CP}\right)$ as the case may be. Applying the homogeneous approach to O\&M systems would imply that a single generic partnership for O\&M can be derived and would lead to equivalent levels of performance for all the different O\&M subsystems or functionalities. In view of complexities that exist in an irrigation scheme, it is important to consider an irrigation scheme as consisting of heterogeneous domains (such as Infrastructure, O\&M, governance, production and marketing) which call for different partnerships depending on the key functionality in a given domain for which scheme farmers may require external support.

According to Prefol et al. (2006), private participation in the irrigation sector is in investment, operation and maintenance and production function while public sector participation is mainly in governance functions. While it is an undeniable fact that both public and private partnerships are crucial for effective operation and maintenance of irrigation infrastructure in small-scale irrigation schemes, it is important to analyse the scheme components and identify where these partnerships exist. In this study, attempts have been made to unpack both private and public participation in O\&M by identifying exactly where and how such partnerships are needed for sustainable operation and management of scheme infrastructure.

\section{Methods}

The study was undertaken on one of two schemes which were being rehabilitated as part of piloting a framework for sustainable revitalisation of small-scale irrigation schemes in Zimbabwe.

\subsection{Location of the Study Area}

Rupike irrigation scheme is located $80 \mathrm{~km}$ south of the Masvingo City, in the Masvingo District of the Masvingo Province (Figure 1). The road to the scheme from Masvingo City consists of $62 \mathrm{~km}$ tarmac road and $18 \mathrm{~km}$ dirt road. The scheme falls within natural region (NR) 4 of Zimbabwe's agro ecological zones. The main characteristics of the region are: annual rainfall of 450-650 mm, severe dry spells during the rainy season, and frequent droughts. Other characteristics of this NR are: mean minimum temperature range of $11-20{ }^{\circ} \mathrm{C}$; mean 
maximum temperature range of $19-26^{\circ} \mathrm{C}$ and a mean annual temperature range of $18-24{ }^{\circ} \mathrm{C}$ (Mugandani et al., 2012).

\subsection{Details of the Irrigation System}

Rupike irrigation scheme has 200 beneficiaries with each household allocated 0.5 ha plot. Crops grown during the summer season are grain maize, green maize and groundnuts. In winter three crops are grown, namely sugar beans, wheat and mixed vegetables.

The scheme was developed by funding from Rio Tinto Foundation as part of its social responsibility of raising the livelihoods of rural communities through supporting self-help projects, thereby increasing the cost efficiency of food output and other income sources. Rio Tinto Foundation assisted in the operation and maintenance of the irrigation system since its inception in 1989 until 1992 when it was handed over to the farming community. Original scheme plans coupled with a GPS survey were used to produce up-to-date map and plan of the scheme (Figure 2). The scheme map and plan were used to identify details of all the components of the irrigation infrastructure, from the water source to the field.

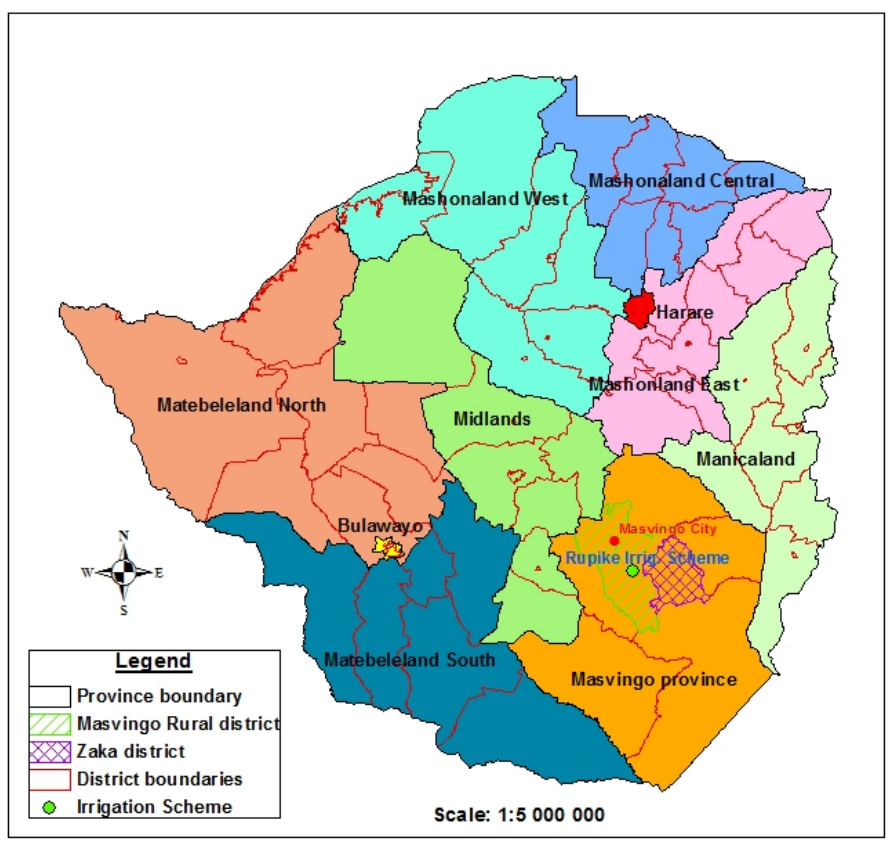

Figure 1. Map of location of Rupike irrigation scheme in Zimbabwe

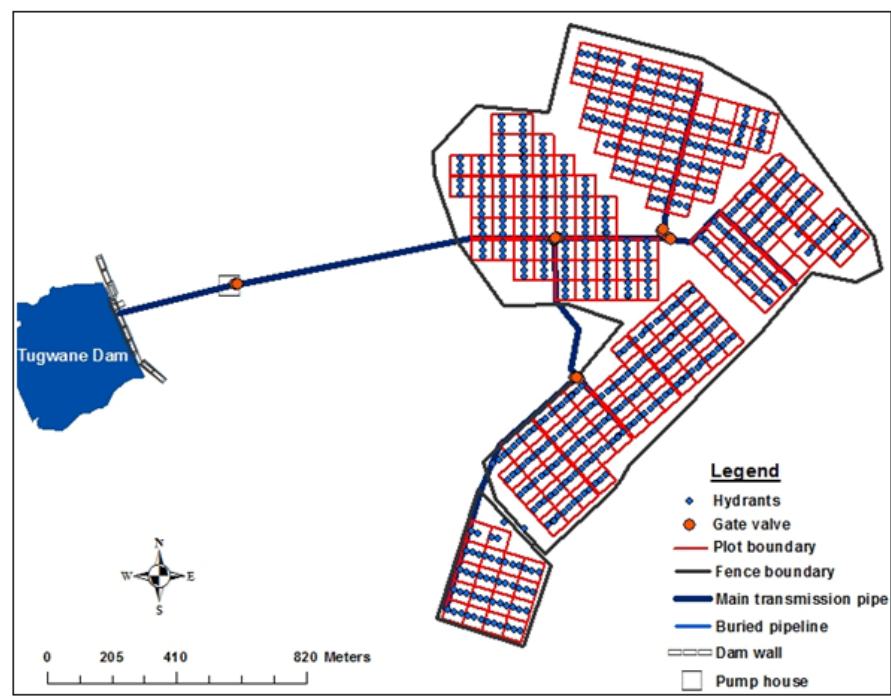

Figure 2. Layout of the main irrigation infrastructure at Rupike irrigation scheme 
The scheme is a sprinkler operating system which draws its water from Tugwane Dam on the Tugwane River. The dam, which was constructed by Rio Tinto, was handed over to the farmers together with the scheme. The dam has a net capacity of $2055000 \mathrm{~m}^{3}$ and a $10 \%$ yield of $2060000 \mathrm{~m}^{3}$ of water. A $400 \mathrm{~mm}$ diameter steel transmission pipe conveys water from the dam over $200 \mathrm{~m}$ distance to a pump house. Water comes into the pump house from the dam by gravity under flooded suction. The pump house contains 4 Ecanorm $80-250$ pumps connected to $60 \mathrm{hp}$ motors. Water is delivered at $128 \mathrm{l} / \mathrm{s}$ into the piped system by three electric motor driven pumps with a fourth set being on standby. At any given time, 3 pumps operate and all irrigators are able to irrigate at the same time running a total of 600 sprinklers. The scheme has a pipeline system consisting of $17 \mathrm{~km}$ main line steel pipe ranging from $350 \mathrm{~mm}$ diameter to $150 \mathrm{~mm}$ diameter and $10 \mathrm{~km}$ of PVC pipes that laterally feed water to the irrigated plots. Each plot has 3 turf hydrants which connect to a $36 \mathrm{~m}, 20 \mathrm{~mm}$ diameter, garden hose pipe that supplies water to a moveable overhead sprinkler mounted on a tripod. Each farmer holds a half hectare plot with three sprinklers.

\subsection{Consultations}

Farmers and Agricultural Technical and Extension Service (AGRITEX) and Department of Irrigation Development (DOI) staff were consulted to verify the details of key component in the O\&M domain of the scheme. At the end of the field assessment and consultations with the farmers and staff of AGRITEX and DOI, the O\&M domain was divided into the main components which require specific operation and maintenance (O\&M) activities.

\subsection{Group Discussions}

In order to identify the specific O\&M activities for each scheme component, views of the farmers were solicited through interviews and group discussions. The group discussion was attended by a total of 96 farmers, 36 female and 60 male farmers, out of the 200 plot holders. The farmers were randomly divided into two groups to encourage participation. The farmers were presented with three possible partnerships namely, public-community partnership $\left(\mathrm{P}_{\mathrm{U}} \mathrm{CP}\right)$, private-public-community participation $\left(\mathrm{P}_{\mathrm{VT}} \mathrm{P}_{\mathrm{U}} \mathrm{CP}\right)$, and private-community partnership $\left(\mathrm{P}_{\mathrm{VT}} \mathrm{CP}\right)$ for $\mathrm{O} \& \mathrm{M}$ in each component. These were selected based on common partnerships in small irrigation schemes in the country. Either of the two groups looked at each component of the O\&M domain and identified operation and maintenance requirements for the component then assigned the requisite partnerships for sustainable O\&M. The types of partnerships the groups identified under the various components are summarised in Table 1.

Table 1. Identified partnerships for O\&M activities at Rupike irrigation scheme

\begin{tabular}{|c|c|c|c|}
\hline O\&Mcomponent & $\begin{array}{l}\text { Proposed } \\
\text { partnership }\end{array}$ & Key partners & Main O\&M activities* \\
\hline \multirow{3}{*}{$\begin{array}{l}\text { Water Acquisition } \\
\text { (Tugwane dam) }\end{array}$} & \multirow{3}{*}{$\begin{array}{l}\text { Public/Communi } \\
\text { ty Partnership } \\
\left(\mathrm{P}_{\mathrm{U}} \mathrm{CP}\right)\end{array}$} & ZINWA* (Public) & $\begin{array}{l}\text { - Carry out routine dam safety inspections } \\
\text { - Record dam water levels and releases to the } \\
\text { irrigation } \\
\text { - Maintain the dam wall embankment and } \\
\text { ensure that it is protected from water erosion }\end{array}$ \\
\hline & & EMA (Public) & $\begin{array}{l}\text { - Monitor dam siltation and put in measures that } \\
\text { protect water body from siltation. } \\
\text { - Enforces bye-laws prohibiting farmers to } \\
\text { carry out stream/river bank cultivation. }\end{array}$ \\
\hline & & $\begin{array}{l}\text { Farmers } \\
\text { (Community) }\end{array}$ & $\begin{array}{l}\text { - Protect the dam wall from damage by } \\
\text { livestock; } \\
\text { - Clear overgrown vegetation along the dam } \\
\text { wall; } \\
\text { - Safeguarding water source against siltation }\end{array}$ \\
\hline
\end{tabular}




\begin{tabular}{|c|c|c|c|}
\hline \multirow{2}{*}{$\begin{array}{l}\text { Water } \\
\text { Transmission } \\
\text { (WT) } \\
\text { (Transmission } \\
\text { pipe) }\end{array}$} & \multirow{2}{*}{$\begin{array}{l}\text { Private/Commun } \\
\text { ity Partnership } \\
\left(\mathrm{P}_{\mathrm{VT}} \mathrm{CP}\right)\end{array}$} & $\begin{array}{l}\text { Private engineering } \\
\text { companies }\end{array}$ & $\begin{array}{l}\text { - Supply and fitting of transmission pipes } \\
\text { - Carry out on site fabrications, welding and } \\
\text { complex pipe repairs; } \\
\text { - Servicing of water meters }\end{array}$ \\
\hline & & $\begin{array}{l}\text { Farmers } \\
\text { (Community) }\end{array}$ & $\begin{array}{l}\text { - Carry out regular inspections of transmission } \\
\text { pipe for leakages and excessive wear; } \\
\text { - Attend to minor leaks in the main line } \\
\text { - Ensure that all pipeline sections exposed are } \\
\text { protected from damage and corrosion. }\end{array}$ \\
\hline \multirow{3}{*}{$\begin{array}{l}\text { Water Pumping } \\
\text { (WP) Pump house }\end{array}$} & \multirow{3}{*}{$\begin{array}{l}\text { Public/Private/C } \\
\text { ommunity } \\
\text { Partnership } \\
\left(\mathrm{P}_{\mathrm{U}} \mathrm{P}_{\mathrm{VT}} \mathrm{CP}\right)\end{array}$} & ZESA (Public) & $\begin{array}{l}\text { - Providing power to the pump house } \\
\text { - Maintain substation (Transformers) and high } \\
\text { voltage line supplying power to pump house }\end{array}$ \\
\hline & & $\begin{array}{l}\text { Private engineering } \\
\text { companies (To } \\
\text { include irrigation } \\
\text { companies and } \\
\text { local Technicians) }\end{array}$ & $\begin{array}{l}\text { - } \\
\text { - } \text { Identify defects } \\
\text { - } \\
\text { Provide pump service kits (bearings, seals, } \\
\text { packing, shafts etc.) } \\
\text { - Carry our pump and motor service and } \\
\text { maintenance }\end{array}$ \\
\hline & & $\begin{array}{l}\text { Farmers } \\
\text { (Community) }\end{array}$ & $\begin{array}{l}\text { - Keeping the pump house and surrounding area } \\
\text { clean. } \\
\text { - Maintaining the pump house building and } \\
\text { perimeter fence }\end{array}$ \\
\hline \multirow{2}{*}{$\begin{array}{l}\text { Water Distribution } \\
\text { (WD) }\end{array}$} & \multirow{2}{*}{$\begin{array}{l}\text { Private/Commun } \\
\text { ity Partnership } \\
\left(\mathrm{P}_{\mathrm{VT}} \mathrm{CP}\right)\end{array}$} & $\begin{array}{l}\text { Private engineering } \\
\text { companies }\end{array}$ & $\begin{array}{l}\text { - Supply piping and related accessories for the } \\
\text { distribution line. } \\
\text { - Carry out on site fabrications, welding and } \\
\text { complex pipe repairs } \\
\text { - Servicing of water meters }\end{array}$ \\
\hline & & $\begin{array}{l}\text { Farmers } \\
\text { (Community) }\end{array}$ & $\begin{array}{l}\text { - Carry out regular inspections of the } \\
\text { distribution line for leakages and excessive } \\
\text { wear; } \\
\text { - Attend to minor leaks in the main line } \\
\text { - Ensure that all pipeline sections exposed are } \\
\text { protected from damage and corrosion. }\end{array}$ \\
\hline \multirow{2}{*}{$\begin{array}{l}\text { Field Water } \\
\text { Application } \\
\text { (WAP) }\end{array}$} & \multirow{2}{*}{$\begin{array}{l}\text { Public/Communi } \\
\text { ty Partnerships } \\
\left(\mathrm{P}_{\mathrm{U}} \mathrm{CP}\right)\end{array}$} & AGRITEX & $\begin{array}{l}\text { - Develop cropping programmes with farmers; } \\
\text { - } \\
\text { - } \\
\text { - Assist farmers in sourcing of inputs; } \\
\text { - Advise and assist farmers on recommended } \\
\text { agronomic and irrigation practices; }\end{array}$ \\
\hline & & DOI & $\begin{array}{l}\text { - Advise farmers on water management } \\
\text { practices especially on irrigation scheduling; } \\
\text { - Ensure equitable distribution of water to all } \\
\text { blocks and farmers; } \\
\text { - Monitor soil salinity, waterlogging and put in }\end{array}$ \\
\hline
\end{tabular}




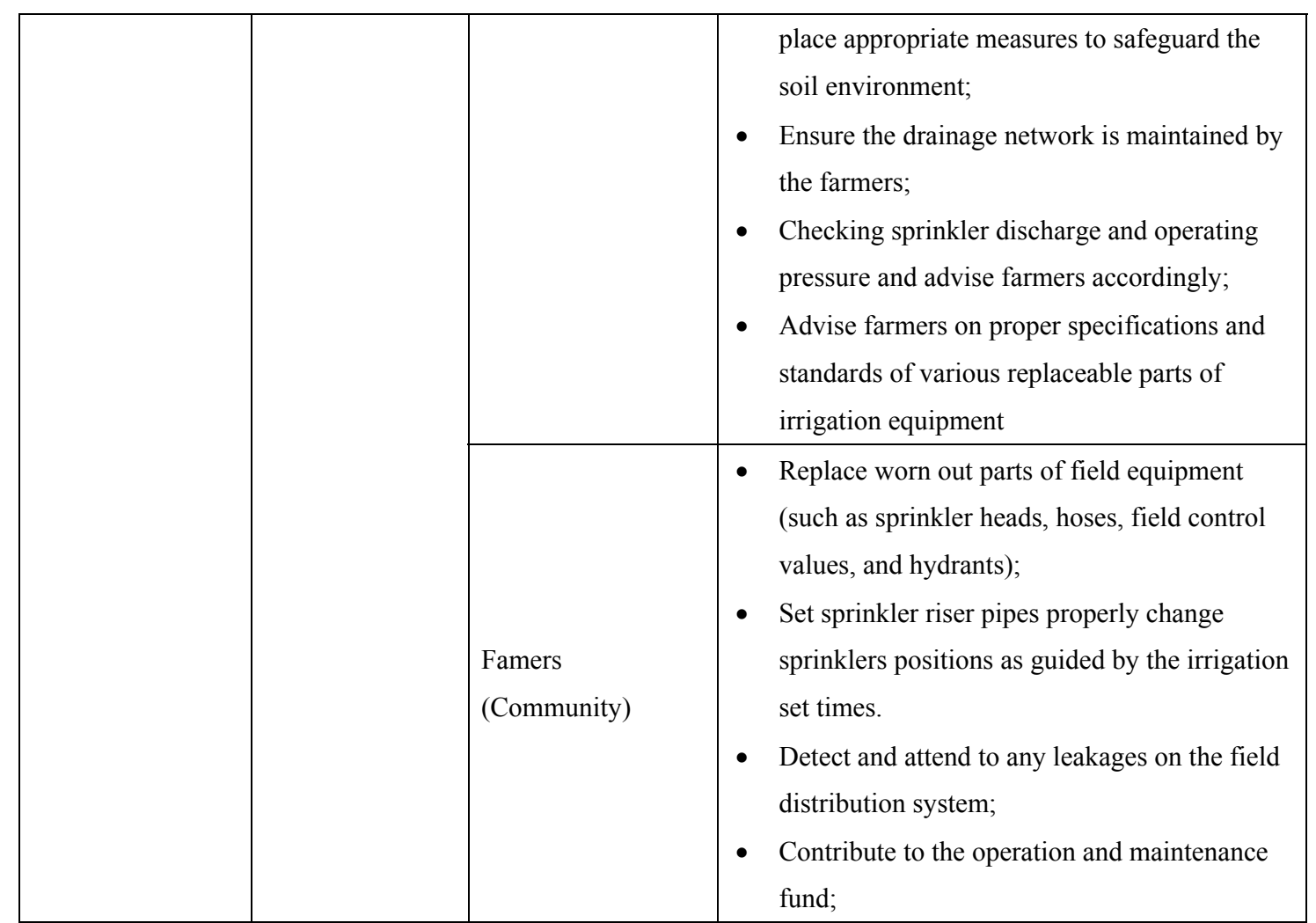

* ZINWA = Zimbabwe National Water Authority; EMA = Environmental Management Agency; ZESA = Zimbabwe Electricity Supply Authority; AGRITEX = Agricultural Technical and Extension Service; DOI = Department of Irrigation Development; $\mathrm{P}_{\mathrm{U}}=$ Public; $\mathrm{P}_{\mathrm{VT}}=$ Private.

\section{Results and Discussions}

\subsection{Irrigation System}

Based on the scheme plan and field survey of the scheme described above, the identified components of the irrigation system for which the farmers requires partnerships for O\&M were water acquisition, water transmission; water pumping; water distribution; and field water application (Figure 3). Thus, the different functionalities that exist in the O\&M domain for this irrigation system are water acquisition (WA), water transmission (WT), water pumping (WP), water distribution (WD), and water application (WAP) in the field. In the context of Rupike Irrigation scheme, the case study of this paper, it became clear that each of these different functionalities within the O\&M domain would require different operational and maintenance partnerships to achieve maximum efficiency and sustainability. The functionalities in the O\&M domain for which partnerships may be required can be expressed as the summation of the various components (Equation 1).

$$
\mathrm{OM}_{\mathrm{T}}=\mathrm{OM}_{\mathrm{WA}}+\mathrm{OM}_{\mathrm{WT}}+\mathrm{OM}_{\mathrm{WP}}+\mathrm{OM}_{\mathrm{WD}}+\mathrm{OM}_{\mathrm{WAP}}
$$

Where $\mathrm{OM}_{\mathrm{T}}=$ overall operation and maintenance domain functions

$\mathrm{OM}_{\mathrm{WA}}=\mathrm{O} \& \mathrm{M}$ of water acquisition component;

$\mathrm{OM}_{\mathrm{WT}}=\mathrm{O} \& \mathrm{M}$ of water transmission component;

$\mathrm{OM}_{\mathrm{WP}}=\mathrm{O} \& \mathrm{M}$ of water pumping component;

$\mathrm{OM}_{\mathrm{WD}}=\mathrm{O} \& \mathrm{M}$ of water distribution component (both mainline and field distribution); and

$\mathrm{OM}_{\mathrm{WAP}}=\mathrm{O} \& \mathrm{M}$ of field water application 


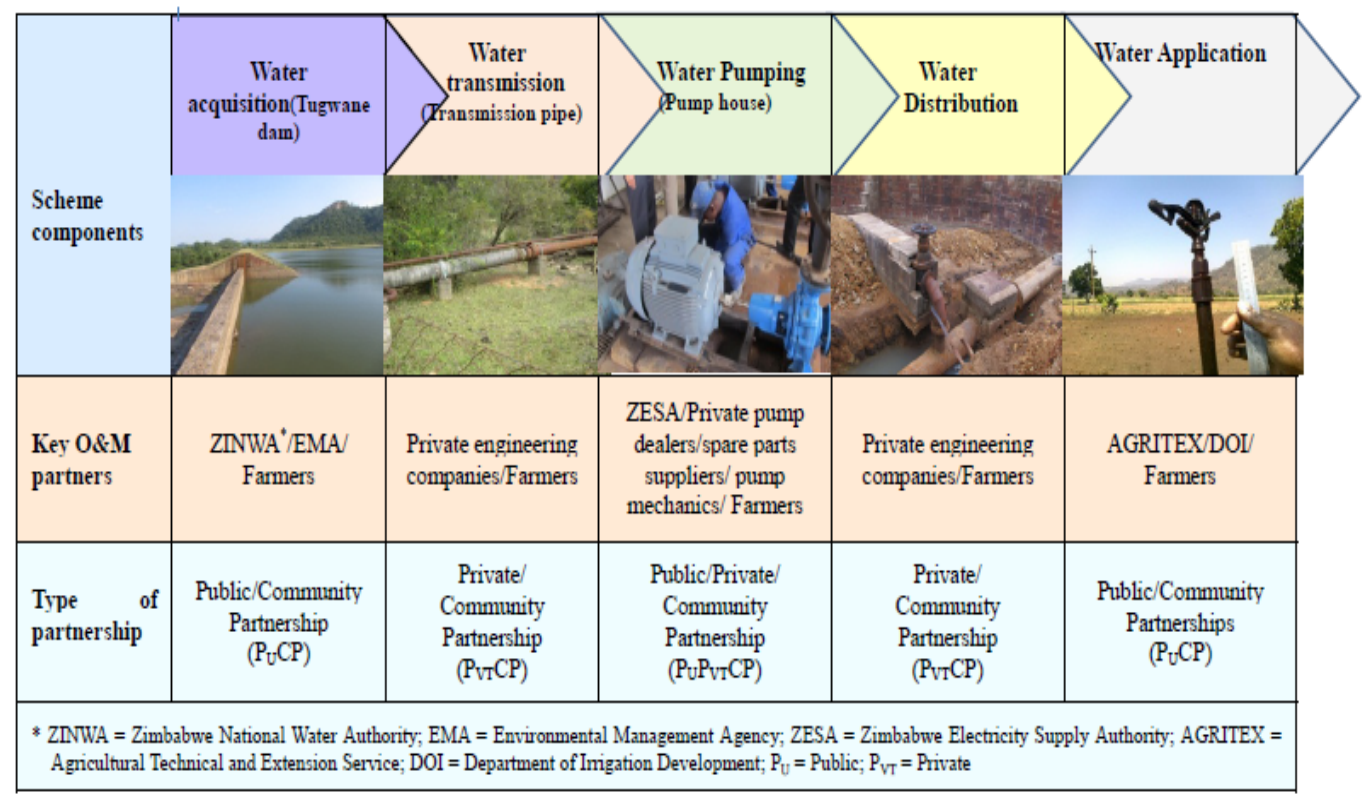

Figure 3. Partnerships for O\&M at Rupike irrigation scheme

The thesis in this paper is that this homogeneous view of a single partnership across the different domains of a scheme is very simplistic and that even in a single domain (e.g. O\&M) there are different functionalities that may require different partnership arrangements to enhance operational and maintenance efficiency.

Although the water source, Tugwane Dam, was handed over to the scheme, it remains the property of the state and as such the proper usage and management of the dam fall under the jurisdiction of the Zimbabwe National Water Authority (ZINWA), a public entity. The other public entity with interest in its usage is the Environmental Management Agency (EMA) which oversees all environmental issues related to management and usage of water bodies in the country. The next component is the transmission pipe which, as a large hydraulic structure, requires specialised services to repair and maintain it. As the farmers do not have capacity to provide such specialised services, they need to partner with private engineering companies to operate and maintain the structure sustainably. The pumps in the pump house are powered by electricity supplied by the Zimbabwe Electricity Supply Authority (ZESA). Operating and maintaining the pumping units require the services of competent technical personnel. The scheme has capacity to deal with routine maintenance activities. However, it requires the assistance of pump specialists to deal with emergency maintenance activities. Hence, the farmers need to partner with private entities such as pumps dealers and mechanics in order to effectively operate and maintain the pumping units under such conditions.

The water distribution component consists of $350 \mathrm{~mm}$ diameter steel distribution pipeline, $300 \mathrm{~mm}$ diameter steel main line pipes and $200-150 \mathrm{~mm}$ diameter PVC field pipes. The ancillary parts include main control valves and water meters. While the farmers may have the capacity to operate and maintain the field distribution infrastructure, they need the support of engineering companies for reliable supply of parts and back-up service in cases of emergency maintenance such as carrying out on-site fabrications, welding complex pipe repairs and servicing of water meters.

The final component consists of on-farm irrigation, defined as the irrigation equipment directly owned and managed by the farmer for watering crops together with the associated water management and agronomic practices. In this case the component consists of field turf hydrants, $20 \mathrm{~mm}$ plastic hosepipes, and sprinkler heads mounted on tripods. The water application component includes crop production activities which relate to agronomic and soil management practices. In this case, the farmers require the assistance of specialists in proper agronomic, cropping patterns, soil management practices and proper irrigation management practices. These services are provided by AGRITEX and DOI, both public agencies. AGRITEX supports the farmers by providing technical advice in cropping pattern, crop budgets, sourcing of inputs, and recommended agronomic and irrigation practices. The DOI provides support to the farmers in appropriate irrigation scheduling, monitor 
soil salinity, waterlogging, checking sprinkler discharge and operating pressure, and advise farmers on proper specifications and standards of various replaceable parts of irrigation equipment.

\subsection{Current O\&M System}

According to the current system, the irrigation system is divided into two components for operation and maintenance purposes. These components are the pumps and water delivery network to the plots and the water application equipment within each plot. Each farmer is responsible for maintaining irrigation equipment within the plot. Although the farmers got full control of the scheme in 1992, they (the farmers) continued to rely on Rio Tinto for support with O\&M of the infrastructure, particularly with the pumping system. The farmers contribute USD10 each per year which is supposed to cover maintenance costs for the pump attendant, irrigation clerk, the pump station and the water delivery system. However, during the group discussion, the farmers indicated that the USD10 per farmer per year is not enough to meet the operational and maintenance costs. They indicated that, due to economic hardships the scheme had been experiencing, they cannot afford to raise the fee to any meaningful level. They, however, proposed to increase their contribution should the performance of the scheme improve after rehabilitation. The other challenges are that some farmers default payments and the Irrigation Management Committee (IMC) fails to enforce the irrigation byelaws that stipulate punishing members that default payments.

\subsection{Proposed Partnerships for O\&M}

The proposed O\&M partnerships for the scheme are based on the analysis of the types of operations involved in the entire spectrum of the scheme operation and maintenance domain, from water acquisition (water source), water transmission, water pumping, water distribution, to water application. The O\&M model presented in Equation 1 implies that one can express the overall partnership for O\&M in the scheme as the summation of the partnerships in the various components (Equation 2):

$$
\mathrm{P}_{\mathrm{O} \& \mathrm{M}}=\left(\mathrm{P}_{\mathrm{U}} \mathrm{CP}\right)_{\mathrm{AW}}+\left(\mathrm{P}_{\mathrm{VT}} \mathrm{CP}\right)_{\mathrm{WT}}+\left(\mathrm{P}_{\mathrm{U}} \mathrm{P}_{\mathrm{VT}} \mathrm{CP}\right)_{\mathrm{WP}}+\left(\mathrm{P}_{\mathrm{VT}} \mathrm{CP}\right)_{\mathrm{WD}}+\left(\mathrm{P}_{\mathrm{U}} \mathrm{CP}\right)_{\mathrm{WAP}}
$$

Where $\mathrm{P}_{\mathrm{O} \& \mathrm{M}}=$ overall partnership for O\&M domain

$$
\begin{aligned}
& \left(\mathrm{P}_{\mathrm{U}} \mathrm{CP}\right)_{\mathrm{WA}}=\text { Public/Community Partnership (ZINWA/EMA/Farmers) } \\
& \left(\mathrm{P}_{\mathrm{VT}} \mathrm{CP}\right)_{\mathrm{WT}}=\text { Private/Community Partnership (private engineering companies/Farmers) } \\
& \left(\mathrm{P}_{\mathrm{U}} \mathrm{P}_{\mathrm{VT}} \mathrm{CP}\right)_{\mathrm{WP}}=\begin{array}{l}
\text { Public/Private/ Community Partnership (ZESA/Private pump dealers/spare parts } \\
\text { suppliers/ pump mechanics/ Farmers) }
\end{array} \\
& \left(\mathrm{P}_{\mathrm{VT}} \mathrm{CP}\right)_{\mathrm{WD}}=\text { Private/ Community Partnership (Private engineering companies/Farmers) } \\
& \left(\mathrm{P}_{\mathrm{U}} \mathrm{CP}\right)_{\mathrm{WAP}}=\text { Public/Community Partnerships (AGRITEX/DOI/Farmers }
\end{aligned}
$$

The study has shown that farmers' ability to operate and manage the infrastructure is limited by their technical expertise and lack of appropriate tools and equipment. The scheme needs the support of ZINWA in the development, use, and management of their water resources since water is a public resource. This is where the schemes need public-community partnership $\left(\mathrm{P}_{\mathrm{U}} \mathrm{CP}\right)$. The scheme also needs the partnership with EMA to ensure that the use and management of the water source are done in compliance with the national environmental regulations.

The farmers use electricity to power their pumping units, hence they need partnership with Zimbabwe Electricity Supply Authority (ZESA) for the power and private company or individuals for repairing and maintaining the pumps and motors. Since ZESA is a parastatal company, the partnership the scheme has in this section is public/private community partnership $\left(\mathrm{P}_{\mathrm{U}} \mathrm{P}_{\mathrm{VT}} \mathrm{CP}\right)$. As for transmission and distribution components, the farmers require the services of private companies to provide spares for field equipment as well as helping them on how to service and maintain the infrastructure. These are areas where the farmers require private-community partnerships $\left(\mathrm{P}_{\mathrm{VT}} \mathrm{CP}\right)$. In the section of field water application and crop production, the farmers require technical support on irrigation management from DOI and on best agronomic practices from AGRITEX. This is where they need public-community partnership $\left(\mathrm{P}_{\mathrm{U}} \mathrm{CP}\right)$.

It was proposed that various partnerships the farmers need to enter into must be formalised through some form of contracts between the scheme and the party involved. The farmers agreed to improve financing O\&M through increased contribution once the scheme performance improves after revitalisation. It was observed that the process of revitalisation would include revamping the scheme's governance systems and hence result in improved enforcement of the scheme's bylaws. It was also observed that partnerships with the private sector 
offer the farmers the needed managerial and/or operational expertise and efficiency, leading to better quality and perhaps a lower cost. On the other hand, $\mathrm{P}_{\mathrm{VT}} \mathrm{CPs}$ present business opportunities in areas from which the private sector was previously excluded.

\section{Conclusion}

It is important that scheme farmers are fully involved in O\&M since inadequate and deferred O\&M is likely to seriously compromise the productivity and effectiveness of a rehabilitated infrastructure. The study has shown that the constraints to the efficient performance of the irrigation schemes include limited capacity of the schemes in effective operation and maintenance (O\&M) of the irrigation infrastructure and inadequate O\&M planning and funding mechanisms that result in chronic system deterioration. To address these, it is proposed to reform the irrigation service delivery by introducing an O\&M model in which the farmers engage into appropriate and effective partnerships with the public (government agency) and private institutions for the operation and maintenance of the various components of the irrigation system. It is also proposed that, in cases of formalised partnerships, such partnerships should be based on performance-based service agreements for O\&M of the irrigation systems. It was recommended that the farmers improve funding for O\&M through increased contributions as well as through partnerships with the private sector. While it is an undeniable fact that both public and private partnerships are crucial for effective operation and maintenance of irrigation infrastructure in small-scale irrigation schemes, it was also recommended that, for effective partnerships, it is important to analyse the scheme components and identify where and how such partnerships are needed for O\&M of scheme infrastructure.

\section{Acknowledgement}

The study was part of the project supported by the Swiss Agency for Development and Cooperation (SDC), Pretoria, South Africa. The authors thank the farmers and staff of Rupike Irrigation scheme. The contribution and support of IWMI researchers at IWMI-SA office is gratefully acknowledged. The contribution of staff from AGRITEX and Department of Irrigation Development, Ministry of Agriculture, Mechanization and Irrigation Development (MoMID) is acknowledged.

\section{References}

Abernethy, C. L. (2002). Enabling environments, financing mechanism and equitable access to irrigation. In H. Sally \& C. L. Abernethy (Eds.). Private irrigation in Sub-Saharan Africa: Regional Seminar on Private Sector Participation and Irrigation Expansion in Sub-Saharan Africa, Accra, Ghana, 22-26 October 2001. (pp. 197-211). Colombo, Sri Lanka: IWMI; FAO; CTA-EU Technical Centre for Agricultural and Rural Cooperation.

Bembridge, T. J. (2000). Guidelines for Rehabilitation of Small-scale Farmer Irrigation Schemes in South Africa. WRC Report No. 891/1/00, Water Research Commission, Pretoria.

Biswas, A. K. (1984). Monitoring and evaluation of an irrigation system. International Journal of Water Resources Development, 2(1), 3-25. http://dx.doi.org/10.1080/07900628408722304

Bos, M. G., Burton, M. A., \& Molden, D. J. (2005). Irrigation and Drainage Performance Assessment: Practical Guidelines. CABI Publishing, London, UK.

Chancellor, F. M., \& Hide, J. M. (1997). Smallholder Irrigation: Ways Forward; Guidelines for achieving appropriate scheme design. Volume 1: Guidelines. Report OD 136, TDR Project R5830, HR Wallingford Ltd, Wallingford, UK.

Chibisa, P., Mautsa, A., \& Mukoto, B. (2008). Smallholder irrigation schemes in Nyanga north as strategies for poverty reduction and sustainable rural livelihoods. Journal of Sustainable Development in Africa, 10(2), 653-676.

De Lange, M., Adendorff, J., \& Crosby, C. T. (2000). Developing Sustainable Small-Scale Farmer Irrigation in Poor Rural Communities: Guidelines and Checklists for Trainers and Development Facilitators. WRC Report No. 774/1/00. Water Research Commission, Pretoria.

Degǐrmenčr, H., Büyükcangz, H., \& Kuşcu, H. (2003). Assessment of Irrigation Schemes with Comparative Indicators in the South-eastern Anatolia Project. Turkish Journal of Agriculture and Forestry, 27, 293-303.

Fanadzo, M. (2012). Revitalisation of smallholder irrigation schemes for poverty alleviation and household food security in South Africa: A review. African Journal of Agricultural Research, 7(13), 1956-1969. http://dx.doi.org/10.5897/AJARX11.051 
FAO. (1999). Realizing the value of irrigation system maintenance. IPTRID Issues Paper No. 2, Food and Agriculture Organization of the United Nations, Rome.

Gorantiwar, S. D., \& Smout, I. K. (2005). Performance assessment of irrigation water management of heterogeneous irrigation schemes: 1. A framework for evaluation. Irrigation and Drainage Systems, 19, 1-36. http://dx.doi.org/10.1007/s10795-005-2970-9

Hedayat, N. (2011). Complexity of Operation and Maintenance in Irrigation Network Management-A Case of the Dez Scheme in the Greater Dezful, Iran. World Academy of Science, Engineering and Technology, 57, 728-731.

Hill, R. W., Patterson, R., \& Barnhill, J. V. (2008). Small Acreage Irrigation System Operation and Maintenance.AG/Small Acreage/ 2008-01pr, Cooperative Extension, Utah State University, Logan, UT. Retrieved from http://extension.usu.edu/htm/counties

Inocencio, A., Kikuchi, M., Tonosaki, M., Maruyama, A., Merrey, D. Sally, H., \& de Jong, I. (2007). Costs and Performance of Irrigation Projects: A Comparison of Sub-Saharan Africa and Other Developing Regions. Research Report 109, International Water Management Institute Colombo, Sri Lanka, p. 81.

Jurriens, M., \& Jain, K. P. (Eds). (1993). Maintenance of Irrigation and Drainage Systems: Practices and experiences in India and. WALMI/ILRI, New Delhi, India, p. 251.

Kamara, A., Van Koppen, B., \& Magingxa, L. (2001). Economic viability of small-scale Irrigation Systems in the Context of State Withdrawal: The Arabia Scheme in the Northern Province of South Africa, WaterNet Symposium, Cape Town.

Kuscu, H., Bölüktepe, F. E., \& Demir, A. O. (2009). Performance assessment for irrigation water management: A case study in the Karacabey irrigation scheme in Turkey. African Journal of Agricultural Research, 4(2), 124-132.

Mishra A, Ghosh, S., Nanda, P., \& Kumar, A. (2011). Assessing the impact of rehabilitation and irrigation management transfer in minor irrigation projects in Orissa, India: a case study. Irrigation and Drainage, 60, 42-56. http://dx.doi.org/10.1002/ird.540

Mitra, A. K. (1997). Management and Pricing of Irrigation Water.National Bank for Agriculture and Rural Development Mumbai, Mumbai, India, p.103.

Mnkeni, P. N. S., Chiduza, C., Modi, A. T., Stevens, J. B., Monde, N., Van der Stoep, I., \& Dladla, R. (2010). Best Management Practices for Smallholder Farming on Two Irrigation Schemes in the Eastern Cape and Kwazulu-Natal through Participatory Adaptive Research. WRC Report No.TT 478/10. Water Research Commission, Pretoria.

Morales, A. C., \& Mongcopa, C. J. (2008). Best practices in irrigation and drainage: Learning from successful projects. A Case Study from the 2006 Annual Evaluation Review, Operations Evaluation Department, Asian Development Bank, Manila, Philippines.

Mugandani, R., Wuta, M., Makarau, A., \& Chipindu, B. (2012). Re-classification of agro-ecological regions of Zimbabwe in conformity with climate variability and change. African Crop Science Journal, 20(2), 361-369.

Oriola, E. O. (2012). Partnership in irrigation system for increased efficiency and agricultural productivity in Nigeria. Journal of Environmental Research and Development, 6(4), 1109-1118.

Prefol, B., Tardieu, H., Vidal, A., Fernandez, S., Plantey, J., \& Darghouth, S. (2006). Public-private partnership in irrigation and drainage: need for a professional third party between farmers and government. Irrigation and Drainage, 55, 253-263.

Renault, D., \& Godaliyadda, G. G. A. (1999). Generic typology for irrigation systems operation.Research Report 29. International Water Management Institute, Colombo, Sri Lanka.

Shah, T., van Koppen, B., Merrey, D., de Lange, M. and Samad, M. (2002). Institutional alternatives in African smallholder irrigation: Lessons from international experience with irrigation management transfer. Research Report 60: International Water Management Institute, Colombo, Sri Lanka.

Sishuta, B. (2005). Small-scale irrigation development for sustainable rural development: AQ case study of the Tyhefu Irrigation scheme. African Sociology Review, 9(2), 184-206.

Small, L. E., \& Svendsen, M. (1990). A framework for assessing irrigation performance. Irrigation and 
Drainage Systems, 4, 283-312. http://dx.doi.org/10.1007/BF01103710

Small, L. E., Adriano, M. S., Martin, E. D., Bhatia, R., Shim, Y. K., \& Pradhan, P. (1989). Financing irrigation services: A literature review and selected case studies from Asia.International Water Management Institute (WMI), Colombo, Sri Lanka, p. 286.

Snellen, W. B. (1996). Irrigation Scheme Operation and Maintenance.Irrigation Water Management Training Manual No. 10, International Institute for Land Reclamation and Improvement, Food and Agriculture Organization of the United Nations, Rome.

Tafesse, M. (2003). Small-scale irrigation for food security in sub-Saharan Africa.CTA Working Document Number 8031, The ACP-EU Technical Centre for Agricultural and Rural Cooperation (CTA). Wageningen, The Netherlands.

World Bank. (2006). Reengaging in Agricultural Water Management: Challenges and Options-Challenges and options. The International Bank for Reconstruction and Development/TheWorld Bank, Washington, DC.

World Bank. (2007). Emerging Public-Private Partnerships in Irrigation Development and Management. Water Sector Board Discussion Paper Series, Paper No. 10, The World Bank, Washington, DC.

\section{Copyrights}

Copyright for this article is retained by the author(s), with first publication rights granted to the journal.

This is an open-access article distributed under the terms and conditions of the Creative Commons Attribution license (http://creativecommons.org/licenses/by/3.0/). 